\title{
HRVATSKI TISAK NA PODRUČJU DANAŠNJE MAĐARSKE U GODINAMA NAKON PRVOG SVJETSKOG RATA
}

UDK 070(94=511.141)“19“

Pregledni rad

Primljeno: 17. 6. 2019.

\begin{abstract}
U godinama nakon Prvog svjetskog rata (1918.-1921.) na području današnje Mađarske izmijenilo se nekoliko državnih formacija. Cilj ovoga rada je razotkriti postojanje hrvatskih izdanja (knjige, periodika, sitni tisak) koja nastaju u ovom razdoblju na području današnje Mađarske i izravno ili neizravno su povezana s ustanovama ili pojedincima koje financira država. Rad se temelji na popisu koji sakuplja hrvatska izdanja objavljena od 1918. do 2015. na području današnje Mađarske. Budući da je nakladništvo za manjine u Mađarskoj u tematiziranom razdoblju čvrsto povezano s državnim ustanovama, jedan dio rada posvećen je manjinskoj politici Mađarske u ovom razdoblju. Uvidom u sadržaj izdanja stječe se dojam da je riječ o nakladništvu s jakim propagandnim karakterom.

Ključne riječi: Hrvati u Mađarskoj, nakladništvo, manjinska politika, Mađarska Demokratska Republika, Mađarska Sovjetska Republika, srpska okupacija Pečuha i Baranje
\end{abstract}

\section{Uvod}

U ovom radu će se opisati hrvatsko nakladništvo (monografske publikacije, serijska izdanja, sitni tisak) na području današnje Mađarske u godinama poslije Prvog svjetskog rata (1918.-1921.). Predstavit će se izdanja koja su objavljena na hrvatskom jeziku ili za hrvatsku publiku, a pri tome će povezanost državnih ustanova ili pojedinaca s nakladnicima i autorima (stvarateljima sadržaja) dobiti posebnu pozornost. Uvidom u korpus stječe se dojam da u slučaju ovih izdanja većinom možemo govoriti o tendencioznim tekstovima, koji su za hrvatsku zajednicu u Mađarskoj objavljeni radi širenja određenih ideja i misli (prvenstveno političkih). Budući da je ovo razdoblje u povijesti 
Mađarske i okolnih zemalja bilo izrazito turbulentno i nestabilno, iz aspekta hrvatskog tiska potrebno je dodatno razlikovati još najmanje tri razdoblja u sklopu toga: 1. Mađarska Demokratska Republika (16. studenog 1918. - 21. ožujka 1919.); 2. Mađarska Sovjetska Republika (21. ožujka 1919. - 1. kolovoza 1919.); 3. Srpska okupacija južne Mađarske (13. studenog 1918. - 20. kolovoza 1921.). ${ }^{1}$

Ovaj rad se temelji na popisu hrvatskih izdanja objavljenih od 1918. do 2015. na području današnje Mađarske. Kriteriji popisa i metode prikupljanja jedinica opisani su u radu „Nakladnička djelatnost Hrvata u Mađarskoj - Pristup korpusu, izazovi, interpretacijske mogućnosti“. ${ }^{2}$ Manjinski tisak u tematiziranom razdoblju (1918.-1921.) zapravo je nepoznato područje, o njemu se govori tek na marginama pojedinih istraživanja koja se bave manjinskom politikom Mađarske u 20. stoljeću. ${ }^{3}$ Kako bi se manjinsko izdavaštvo u Mađarskoj smjestilo u kontekst tadašnje manjinske, državne te međudržavne politike, poslužili smo se prvenstveno povijesnim sintezama koje obrađuju veća razdoblja. ${ }^{4}$

Prvi svjetski rat jedna je od najvažnijih povijesnih prekretnica za Hrvate u Mađarskoj. ${ }^{5}$ Naime, nakon toga ova zajednica se odvaja od svoje matice i odsječeni su stoljetni kanali komunikacije s njom. Ishod i posljedice rata snažno će utjecati na odnos Mađarske prema domicilnoj državi (tada Državi SHS i Kraljevstvu SHS). Kako bi se u sklopu međunarodnih zbivanja bolje shvatila manjinska problematika u Mađarskoj prije i poslije Prvog svjetskog rata, u prvom poglavlju ukratko će se govoriti o takozvanom manjinskom pitanju u Ugarskoj i Mađarskoj prije i poslije Prvog svjetskog rata.

\section{Narodnosno pitanje u Mađarskoj prije i poslije Prvog svjetskog rata}

Takozvano „manjinsko ili narodnosno pitanje“ u Mađarskoj igralo je ključnu ulogu u razdoblju dualizma (Austro-Ugarske Monarhije) te u godinama nakon Prvog svjetskog rata, kada su ove zajednice formirale nove države

${ }^{1}$ Iako je tzv. Horthyjevo razdoblje u Mađarskoj započelo već 1. ožujka 1920., hrvatsko nakladništvo u ovom razdoblju obradit će se u sklopu posebnoga rada.

2 Silvestar Balić, „Nakladnička djelatnost Hrvata u Mađarskoj - Pristup korpusu, izazovi, interpretacijske mogućnosti“, Studia Slavica Savariensia, 2016, 1-2: 30-37. DOI: 10.17668/ SSS.2016.1-2.30

${ }^{3}$ Vidi radove u popisu literature: Beller, 1969; Szabó, 2016; Kővágó, 1969; Iglói, 1966.

${ }^{4}$ Manjinsku politiku u Mađarskoj tijekom 20. stoljeća iscrpno obrađuje Tilkovszky (1998), dok o razdoblju prije i poslije Prvog svjetskog rata detaljno govori petotomno izdanje Mađarska u XX. stoljeću (Magyarország a XX. században).

${ }^{5}$ Vjerojatno najvažnija nakon osmanskih osvajanja jugoistočne i srednje Europe od 15. do 18. stoljeća, zbog kojih hrvatske skupine nastanjuju južne i zapadne krajeve današnje Mađarske. 
na područjima koja su prije rata pripadala nekadašnjoj Kraljevini Ugarskoj. Naravno, to ne znači da ono nije bilo na dnevnom redu i prije 1867. (naročito za vrijeme Revolucije 1848./49.), ali s jačanjem nacionalnih pokreta unutar i izvan države mađarski politički krugovi u narodnosnim zajednicama vide sve veću opasnost, zbog čega će ovo pitanje biti jedno od najvažnijih sve do kraja 1. svj. rata. ${ }^{6}$

Krajem 18. i početkom 19. stoljeća, kada pojam „mađarske nacije“ dobiva svoja konačna obilježja, predstavnici mađarskog nacionalnog pokreta su bili uvjereni da će narodnosti putem usvajanja mađarskog jezika i kulture samovoljno prihvatiti mađarski identitet. Zbog sličnih pokreta narodnosti unutar tadašnje Ugarske, koji su se također temeljili na jeziku te kasnije kulturi, brzo se ispostavilo da ova borba mađarskog nacionalnog projekta neće biti tako jednostavna. Poučen realnim stanjem, mađarski nacionalni pokret tijekom 40-ih godina 19. stoljeća formira koncept mađarske političke nacije (mađ. magyar politikai nemzet). Sastavni dio ove političke zajednice su sve narodnosti (mađ. nemzetiség) u Ugarskoj, ali samo jedna od njih ima politički legitimitet. ${ }^{7}$ Prema tome, Mađari u tadašnjoj Ugarskoj priznati su politički i etnički, a nemađarsko stanovništvo samo na razini narodnosti, odnosno kulturno-jezične raznolikosti. Ovaj koncept je ostao na snazi u Ugarskoj sve do kraja 19. stoljeća, a ovisno o političkoj orijentaciji imao je tri pravca: 1. potpuna jezična asimilacija narodnosti, 2. prihvaćanje jezične šarolikosti narodnosti, 3. prihvaćanje stava manjina da je za njih ovaj koncept neprihvatljiv. ${ }^{8}$

Nakon što su Austrija i Ugarska sklopile Nagodbu, otvorila se mogućnost da Ugarska u sklopu svoje autonomije riješi narodnosno pitanje. U višenacionalnoj državi s velikim brojem nemađarskog stanovništva, nakon više od godinu i pol dana pripreme i rasprave, donesen je manjinski zakon $1868 .{ }^{9}$ U praksi se pokazalo (već za vrijeme priprema i rasprava) da dvije strane

${ }^{6}$ Jedan od najznačajnijih mađarskih političara razdoblja, József Eötvös, u svom tekstu iz 1965. pod naslovom „Narodnosno pitanje“(,A nemzetiségi kérdés“) navodi kako je narodnosno pitanje trenutno jedno od najvažnijih, gorućih pitanja. Báró Eötvös József, A nemzetiségi kérdés (Pest: Ráth Mór, 1865), pristup ostvaren 30. III. 2020., https://mek.oszk.hu/06800/06839/ pdf/06839.pdf.

${ }^{7}$ U sklopu Zemalja Krune sv. Stjepana Mađari su jedino Hrvatima priznali slična prava na području vlastite uprave, a dokaz toga je i posebna nagodba s Hrvatskom koja joj je pružila autonomiju na raznim područjima. József Galántai, A Habsburg-monarchia alkonya: Osztrákmagyar dualizmus, 1867-1918 (Budapest: Kossuth, 1985), 183.

${ }^{8}$ Galántai, A Habsburg-monarchia alkonya, 175.

${ }^{9} \mathrm{O}$ važnosti zakona u tadašnjem političkom ozračju svjedoči činjenica da je Ugarski parlament prihvatio inačicu koju je doradio Ferenc Deák, ponajveća politička ličnost razdoblja. Nacrt manjinskih predstavnika uopće nije prihvaćen, stoga oni nisu sudjelovali u parlamentarnoj raspravi prijedloga. Demeter M. Attila, „Politikai nemzet versus nemzetiség - 1848, 1861, 1868“, u: Nemzet, faj, kultúra a hosszú 19. században Magyarországon és Európában (Budapest: MTA Bölcsészettudományi Kutatóközpont, Történettudományi Intézet, 2016), 251. 
teško dolaze do zajedničkog stava. Zakon nije priznavao narodnosna prava na kolektivnoj, već samo na individualnoj razini ${ }^{10} \mathrm{i}$ također je nastao u duhu jedinstvene mađarske političke nacije, što zastupnici manjina nikako nisu mogli prihvatiti. Razlog tomu je bio strah mađarskih krugova od teritorijalnih pretenzija narodnosti, što bi moglo rezultirati teritorijalnom autonomijom te na kraju odcjepljenjem ili priključenjem matičnim državama narodnosti u susjedstvu, o čemu mađarski krugovi, naravno, nisu htjeli ni čuti, već su provodili politiku asimilacije u nadi da će mađarizacija narodnosti biti brza $\mathrm{i}$ uspješna, te će one odustati od takvih želja samovoljno. ${ }^{11}$ Unatoč svemu tome, manjinski zakon iz 1868. bio je poticajan za razvoj jezika i kulture manjinskih zajednica, što potvrđuje pojačana nakladnička djelatnost i u slučaju Hrvata na ovom području. ${ }^{12}$

Određeni politički krugovi u Mađarskoj nakon nagodbe, poput vlade Kálmána Tisze,$^{13}$ pomirbu s narodnostima već nisu smatrali važnom; štoviše,

${ }^{10}$ Zoltan Ács, Nemzetiségek a történelmi Magyarországon (Budapest: Kossuth, 1986), 273.

${ }^{11}$ Manjinski zakon iz 1868. nije odgovarao zapravo ni narodnostima ni mađarskim nacionalistima. Na nižim razinama nije bilo želje za provođenjem zakona, dok u slučaju kršenja zakona nije bio propisan nikakav pravni lijek. Galántai, A Habsburg-monarchia alkonya, 197-198. Mišljenje mađarskih krugova o „blagoj“ asimilaciji očituje se i u izjavi Józsefa Eötvösa za vrijeme parlamentarne rasprave o manjinskom zakonu iz 1868. Ministar vjere i obrazovanja, tadašnji stručnjak za narodnosti, na kritike manjinskih predstavnika, koji su uglavnom napadali prijedlog zakona zbog distinkcije kolektivnih i individualnih prava, doveo je u pitanje samo postojanje narodnosti, tvrdeći da civilizacija iziskuje žrtve, zbog čega se i manje, necivilizirane narodnosti trebaju utopiti u veće. Demeter, „Politikai nemzet versus nemzetiség - 1848, 1861, 1868“", 252.

${ }_{12}$ Pojačana nakladnička djelatnost na području današnje Mađarske za vrijeme Austro-Ugarske Monarhije u slučaju Hrvata primjećuje se kod podunavskih te gradišćanskih Hrvata. O tome detaljnije: Matija Evetović i Lazar Ivan Krmpotić, Život i rad biskupa Ivana Antunovića narodnog preporoditelja, prošireno izdanje (Pečuh: Hrvatski znanstveni zavod, 2002); Robert Skenderović, Povijest podunavskih Hrvata (Bunjevaca i Šokaca) (Subotica: Zavod za kulturu vojvođanskih Hrvata; Slavonski Brod: Hrvatski institut za povijest, Podružnica za povijest Slavonije, Srijema i Baranje, 2017); Mario Bara i Tomislav Žigmanov, „Vrela za povijest Hrvata u Vojvodini - monografske publikacije do 1918.“, Godišnjak za znanstvena istraživanja, br. 3 (Subotica: Zavod za kulturu vojvođanskih Hrvata, 2011); Ante Sekulić, „Listovi i časopisi bačkih Hrvata od Ivana Antunovića do 1941.“, Migracijske teme 6 (1990), br. 3: 407-414; Nikola Benčić (ur.), Novine i časopisi gradišćanskih Hrvatov (Željezno: Hrvatsko štamparsko društvo, 1985); Franz Fazokas i Eva Maria Folger, „Die kroatischen Kalender im burgenländisch-westungarischen Raum.“, Burgenländische Heimatblätter 47 (Eisenstadt: Amt der Burgenländischen Landesregierung, 1985), 106-123; Ludwig Kuzmich, „Kulturhistorische Aspekte der burgenlandkroatischen Druckwerke bis 1921 mit einer primären Bibliographie.“, Burgenlaendische Forschungen, Sonderbd. X (Eisenstadt, 1992).

${ }^{13}$ Kálmán Tisza (Geszt/MAĐ, 1830. - Budimpešta, 1902.), mađarski političar, za zastupnika Ugarskoga sabora izabran 1861., suosnivač Liberalne stranke (Szabadelvü Párt), obnašao dužnost ministra unutrašnjih poslova, financija, a od 1875. do 1890. predsjednika ugarske vlade. Jedan od glavnih nositelja mađarske velikodržavne politike. 1883. na mjesto hrvatsko-slavonsko-dalmatinskog bana imenovao Károlya Khuen-Héderváryja. Izvor: „Tisza, 
zabranili su vodeće manjinske organizacije (npr. zatvaranje krovne slovačke organizacije Matice Slovenske 1875.) i istisnuli manjinske političare iz političkog života i državne uprave. Krajnje desni svjetonazor za vrijeme dualizma u Ugarskoj zastupaju premijer Dezső Bánffy (1895.-1899. $)^{14}$ i ministar vjere i obrazovanja Gyula Wlassics ${ }^{15}$ (1895.-1903., plemićka obitelj Vlašić potječe iz Hrvatske). Bánffy je putem asimilacije htio stvoriti etnički homogenu mađarsku državu, dok je Wlassich igrao važnu ulogu u prestrukturiranju škola u duhu mađarizacije. Jedan od velikih problema „mađarskog nacionalnog projekta“" je bila etnička zastupljenost Mađara, koji su za vrijeme dualizma (1881.) činili tek 39 posto od ukupnoga stanovništva (prema materinskom jeziku) ${ }^{16}$ Kako bi se ova slika popravila, ojačava se državni školski sustav u suradnji s crkvenim školama, ${ }^{17} \mathrm{u}$ njima uči sve veći broj učenika, napokon i u naseljima, i tako pruža idealno sredstvo za asimilaciju narodnosti, u čemu će biti vrlo uspješan. ${ }^{18}$ Do 1910 . broj stanovnika s mađarskim materinskim jezikom se povećao s 4 milijuna na $48 \%$ ukupnog stanovništva. ${ }^{19}$

U takvim okolnostima višenacionalna Ugarska ulazi u Prvi svjetski rat i izlazi iz njega kao poražena strana. Novi svjetski poredak je omogućio narodnostima da se priključe već postojećim ili novoutemeljenim državama koje su se formirale djelomice na područjima bivše Ugarske Kraljevine. Jasan iskaz toga je bio Rimski kongres u travnju 1918., na kojemu su narodnosni predstavnici manjina iz Monarhije iskazali svoju želju za odcjepljenjem i formiranjem samostalnih država. Mađarski političari su bili skloni popustiti narodnostima

Kálmán”, u Hrvatska enciklopedija, mrežno izdanje [Zagreb: Leksikografski zavod Miroslav Krleža], pristup ostvaren 30. III. 2020., https://www.enciklopedija.hr/natuknica. aspx?id=61466).

${ }^{14}$ Lóránt Tilkovszky, Nemzetiségi politika Magyarországon a 20. században (Debrecen: Csokonai, 1998), 16.

${ }^{15}$ Tilkovszky, Nemzetiségi politika Magyarországon a 20. században, 18.

${ }^{16}$ Od ukupnih 15.642.102 stanovnika Ugarske, mađarski je materinski jezik 6.206.872 stanovnika. Prema popisu stanovništva iz 1881.: A Magyar Korona országaiban az 1881. év elején végrehajtott népszámlálás eredményei némely hasznos házi állatok kimutatásával együtt (Budapest: Országos Magyar Kir. Statisztikai Hivatal, 1882), 214.

${ }^{17}$ Posebno je pitanje odnos raznih vjerskih zajednica prema mađarizaciji narodnosti. Određeni izvori navode kako su pravoslavna i evangelistička crkva pružale određen otpor prema takvim težnjama države, dok katolička manje. Tilkovszky, Nemzetiségi politika Magyarországon a 20. században, 15.

${ }^{18}$ Tilkovszky, Nemzetiségi politika Magyarországon a 20. században, 15.

${ }^{19}$ Prema popisu stanovništva iz 1910. od ukupnih 20.886.487 stanovnika Ugarske mađarski je materinski jezik 10.050.575 stanovnika. Vidi: A Magyar Szent Korona országainak 1910. évi népszámlálása: 6. rész: Végeredmények összefoglalása (Budapest: Magyar Kir. Központi Statisztikai Hivatal, 1920), 63. Škola je bila efikasna i u širenju pismenosti, što je bilo od ključne važnosti za širenje nacionalnih pokreta, ne samo kod Mađara, već i kod narodnosnih zajednica. 
u zadnjim trenucima Monarhije, ${ }^{20}$ ali ove ponude su stigle prekasno, kada već nije bilo mogućnosti za normalizaciju odnosa. Neuspjelu mađarsku manjinsku politiku prije i za vrijeme Austro-Ugarske Monarhije zaključio je Trianonski sporazum, koji je Mađarska potpisala 4. lipnja 1920. ${ }^{21}$ Mađarska javnost je s ogromnim razočaranjem promatrala odcjepljenje narodnosti i teritorija, prvenstveno stoga što su u Mađarskoj svi vodeći političari, od najliberalnijih pa do šovinista, vjerovali u teritorijalni integritet Ugarske sve do zadnjega časa. ${ }^{22}$

Nakon više godina poslijeratnog perioda, nastala je nova situacija zbog koje je mađarska bila primorana temeljito promijeniti svoju manjinsku politiku. Na području „okljaštrene“ Mađarske ostale su manjinske zajednice čiji je stupanj asimilacije bio veći od onih koje su ostale izvan novih granica, ${ }^{23}$ no i u ovim prilikama je bilo potrebno formirati službeni pristup prema manjinskim zajednicama. Ova manjinska politika, ovisno o određenim političkim i ideološkim orijentacijama, imala je različit pristup prema narodnostima, ali je imala jedan zajednički karakter s aspekta manjinskog nakladništva. Dok su u nagodbenom razdoblju manjinske zajednice i same izdavale svoja izdanja, ${ }^{24}$ istina uz vrlo teške financijske uvjete i jak otpor mađarskih krugova, nakon Prvog svjetskog rata takva izdanja će biti rijetka, a manjinsko nakladništvo će se uvelike temeljiti na državnom proračunu i služiti zapravo aktualnoj državnoj propagandi.

\section{Manjinska politika za vrijeme Mađarske Demokratske Republike (16. studenog 1918. - 21. ožujka 1919.)}

Nakon završetka Prvog svjetskog rata za Mađarsku slijedi razdoblje duboke političke, gospodarske i društvene krize, koja će uzdrmati temelje mađarske državnosti. U roku od nekoliko godina pojavile su se razne političke opcije koje su nudile izlazak iz teške krize, a trajale su svega nekoliko mjeseci

${ }^{20}$ Na primjer, bivši premijer István Tisza u zadnjim danima Monarhije (u rujnu 1918.) obilazi Hrvatsku, Dalmaciju, Bosnu i Hercegovinu, a Oszkár Jászi u listopadu 1918. objavljuje svoju knjigu u kojoj predstavlja koncepciju „Sjedinjenih Dunavskih Država“ o federalizaciji Habsburške Monarhije. Vidi: Dinko Šokčević, „Mađarski politički planovi za rješenje hrvatskog [jugoslavenskog] pitanja“, u: Prekretnice u suživotu Hrvata i Mađara: ustanove, društvo, gospodarstvo i kultura, ur. Pál Fodor, Dinko Šokčević (Budimpešta: Institut za povijesne znanosti Istraživačkog centra za humanističke znanosti Mađarske akademije znanosti, Hrvatski institut za povijest, 2015), 79 i 82.

${ }^{21}$ „Trianon“ u: Hrvatska enciklopedija, mrežno izdanje (Zagreb: Leksikografski zavod Miroslav Krleža), pristup ostvaren 16. VII. 2020., [http://www.enciklopedija.hr].

${ }^{22}$ Gábor Vermes, „A délszláv törekvések és a magyar nacionalizmus az Osztrák-Magyar Monarchiában“, Aetas 9 (1994), br. 2: 218.

${ }^{23}$ Tilkovszky, Nemzetiségi politika Magyarországon a 20. században, 9.

${ }^{24}$ Vidi bilješku br. 12. 
ili čak nekoliko dana. Nakon ovih neuspjelih pokušaja konsolidacije od kraja 1919. počinje se koncentrirati grupacija oko admirala Miklósa Horthyja, ${ }^{25}$ koji raspolaže s lojalnim vojnim kadrom te sve jačom potporom sila Antante. Od 1920. u Mađarskoj i službeno započinje Horthyjevo razdoblje, koje će trajati skoro četvrt stoljeća, sve do 1944. godine. ${ }^{26}$

U listopadu 1918., u roku od mjesec dana, u Mađarskoj su se dogodile promjene koje su bile u zraku već jedno vrijeme i koje su obilježile naredne godine, čak i desetljeća. 17. listopada bivši predsjednik vlade István Tisza u parlamentu izgovara poznate rečenice u kojima priznaje poraz Mađarske u Prvom svjetskom ratu. ${ }^{27} 28$. listopada u Budimpešti izbija tzv. Aster revolucija (mađ. Öszirózsás forradalom) zbog odluke cara Karla IV. i regenta Josipa da umjesto Mihálya Károlyija za predsjednika vlade imenuje grofa Jánosa Hadika. ${ }^{28}$ Pobunjeni vojnici i stanovništvo Budimpešte prisilili su regenta da povuče svoju odluku te je 31. listopada za premijera imenovan Károlyi, a revolucija je završena bez većih sukoba. Tih se dana iz Monarhije izdvajaju Češka (sa Slovačkom) i Hrvatska (priključuje se Državi SHS), u Austriji se formira nova vlada, a 16. studenog Mađarsko narodno vijeće u Budimpešti proglašava Mađarsku Demokratsku Republiku (Magyar Népköztársaság). ${ }^{29}$

Vlada Mihálya Károlyija uživala je široku potporu društva; o tome govori i sastav vlade od raznih slojeva društva i političkih opcija tadašnje elite. Jedna od važnih ličnosti ove vlade bio je Oszkár Jászi, ${ }^{30}$ ministar zadužen za narodnosna pitanja, zagovornik radikalnog liberalnog i demokratskog prevrata $u$ Mađarskoj. Među ostalima, bio je zadužen da vodi pregovore s narodnostima unutar Ugarske o pomirbi, o zajedničkom suživotu. Tijekom ovih pregovora manjinama su ponuđene velike povlastice (izglasana je autonomija Slovaci-

${ }^{25}$ Miklós Horthy de Nagybánya (Kendere/MAĐ, 1868. - Estoril/POR, 1957.), u Prvom svjetskom ratu zapovjednik austrougarske flote, od 1920. do 1944. regent Mađarske. Provodio je revizionističku politiku, povezao se s Mussolinijem i Hitlerom. 1944. Nijemci ga interniraju u Njemačku, nastavlja živjeti u emigraciji kao politički neaktivna osoba, a nakon nekoliko godina odlazi u Portugal. Izvor: „Horthy de Nagybánya, Miklós”, u: Hrvatska enciklopedija, mrežno izdanje, pristup ostvaren: 16. 05. 2019. http://www.enciklopedija.hr

${ }^{26}$ Kako smo u bilješkama spomenuli, zbog dužine te značaja ovoga razdoblja, manjinskim izdavaštvom za vrijeme Horthyja bavit ćemo se u posebnom radu.

27 Šokčević, „Mađarski politički planovi“, 83.

${ }^{28}$ István Kollega Tarsoly, Magyarország a XX. században (Szekszárd: Babits Kiadó, 19962000), https://mek.oszk.hu/02100/02185/html/6.html, pristup ostvaren: 30. III. 2020.

${ }^{29}$ Isto.

30 Oszkár Jászi (Nagykároly/MAĐ, 1875. - Oberlin/SAD, 1957.), pisac, političar, sociolog. Studirao u Mađarskoj, Francuskoj i Engleskoj. Nakon proglašenja Mađarske Sovjetske Republike emigrirao u Beč, a zatim u SAD, gdje se zapošljava kao sociolog na sveučilištu. Izvor: Ágnes Kenyeres (ur.), Magyar életrajzi lexikon, pristup ostvaren: 16. 05. 2019. http:// mek.oszk.hu/00300/00355/html/index.html. 
ma, Rusinima i Nijemcima), ${ }^{31}$ ali većina narodnosti već nije bila sklona rješavanju na „mađarski način“. U jednom kasnijem izvješću Jászi navodi da njegova pacifistička manjinska politika nije obećavala previše uspjeha, ali da je to bila jedina takva politika koja se tada mogla i trebala provesti radi održavanja integriteta povijesne države..$^{32}$ Početkom 1919. godine pojavljuju se sve veći unutrašnjopolitički izazovi za vladajuće (Mihály Károlyi u siječnju je preuzeo dužnost predsjednika republike, dok je za premijera imenovan Dénes Berinkey), naročito u obliku komunista i boljševika koji se u sve većem broju vraćaju iz Rusije. Nakon sve jače djelatnosti komunista (organiziranje nemira, prosvjeda i sl.), bez odanog vojničkog kadra i zbog tzv. Vix note, ${ }^{33}$ koja je značajne dijelove Mađarske stavila pod nadzor rumunjske vojske, 21. ožujka 1919. Károlyi je prisiljen ponuditi ostavku i vlast predaje u ruke komunista.

Karolyijeva vlada još u studenom formira Državni odbor za propagandu (mađ. Országos Propaganda Bizottság), koji je između ostalog zadužen za informiranje manjinskih zajednica na rubnim područjima Mađarske. ${ }^{34}$ Jedan od zadataka Odbora je bilo jačanje povjerenja narodnosti prema Mađarima, zbog čega možemo pretpostaviti da je bilo izdanja i na jeziku manjinskih zajednica. Operativni plan Odbora donosi popis letaka, među kojima se posebno navodi letak na mađarskom jeziku za manjine „Mađarski narod pozdravlja Slovake, Rumunje, Hrvate". ${ }^{35}$ Zbog ovih zadataka Odbor je usko surađivao s Narodnosnim ministarstvom pod vodstvom Jászija. Budući da su se službene mađarske vlasti pribojavale vršiti direktnu propagandu prema manjinama u sklopu Narodnosnog ministarstva (što bi moglo izazvati kritiku Antante), odlučili su takvu djelatnost obavljati putem Državnog odbora za propagandu. ${ }^{36}$

Međutim, ubrzo su se pojavile prve kritike, i to iz Ureda (Ministarstvo) predsjednika Vlade, koji u jednom povjerljivom pismu upućenom Narodnosnom ministarstvu navodi kako se slaže u suštini s radom Odbora, ali su potrebne korekcije u djelatnosti, naročito na polju narodnosti i stranačke politi-

${ }^{31}$ Béla Beller, „A Magyar Népköztársaság és a Tanácsköztársaság nemzetiségi kultúrpolitikája”, Történelmi szemle 1-2 (1969): 3-6.

32 Oszkár Jászi, „Magyar kálvária, magyar feltámadás“, u: Tibor Hetés (ur.), A magyarországi forradalmak krónikája: 1918-1919. (Budapest: Kossuth Könyvkiadó, 1969), 122-124.

${ }^{33}$ Mađ. Vix jegyzék. Nazvana prema potpukovniku Fernandu Vixu, voditelju Antantine misije u Budimpešti (Kollega, Magyarország a XX. században).

${ }^{34}$ Pál Schönwald, „Az Országos Propaganda Bizottság tevékenysége és kiadványai az 1918-as polgári forradalom alatt”, Magyar könyvszemle 85 (1969), br. 1: 20.

${ }^{35}$ Mađarski: „A magyar nép üdvözli a szlovákokat, románokat, horvátokat”. Schönwald, „Az Országos Propaganda Bizottság”, 21.

${ }^{36}$ Suradnja Ministarstva i Odbora, pored propagando-agitacijske djelatnosti, odnosila se i na obostranu razmjenu informacija s obzirom na područja gdje je u velikom broju živjelo manjinsko stanovništvo, logističku pomoć pri širenju propagandnih izdanja i sl. Schönwald, „Az Országos Propaganda Bizottság”, 23. 
ke, gdje je Odbor zauzeo nepoželjan stav ${ }^{37} \mathrm{U}$ slučaju manjinske propagande Odboru se zamjerilo da je u nekoliko slučajeva izdao sadržaje koji čine štetu budućem konfederacijskom uređenju države, ${ }^{38} \mathrm{u}$ koje je tada Karolyijeva vlada još vjerovala.

U razdoblju Mađarske Demokratske Republike do sada nije registrirano izdanje na hrvatskom jeziku koje bi bilo povezano s državnim ustanovama, ${ }^{39}$ ali postoji mogućnost da su na hrvatskom jeziku (ili dijalektima) izdani letci i druga sitna propagandna izdanja, dok tiskanje većih monografskih publikacija, a naročito periodike na hrvatskom jeziku od strane vlasti s velikom vjerojatnošću možemo isključiti. ${ }^{40}$

\section{Manjinska politika i nakladništvo za vrijeme Mađarske Sovjetske Republike (21. ožujka 1919. - 1. kolovoza 1919.)}

Ojačani oslobođenim liderima, komunisti već isti dan (21. ožujka 1919.) formiraju novu vladu pod nazivom Revolucionarno upravno vijeće (mađ. Forradalmi Kormányzótanács) u kojemu su određene djelatnosti posvećene komesarima (mađ. népbiztos). Mada se službeno prikazalo drugačije, glavni lik pokreta u Mađarskoj bio je Bela Kun ${ }^{41}$ jedna od vodećih ličnosti svjetskog komunističkog pokreta u prvim desetljećima 20. stoljeća. Revolucionarni preokret se temeljio na emigrantima koji su za vrijeme Prvog svjetskog rata boravili u Rusiji i pripremali se za preuzimanje vlasti, kako će se to vidjeti

${ }^{37}$ Schönwald, „Az Országos Propaganda Bizottság”, 27.

${ }^{38}$ Isto.

${ }^{39} \mathrm{Na}$ popisu hrvatskih izdanja koja izlaze od 1918. u ovom razdoblju registrirane su sljedeće jedinice (bez točnog nadnevka objave): u Gradišću još izlaze Naše novine (do 1922.), 1918. izlazi Marjanovićev (pravo ime Anton Semeliker) i Dobrovićev Kalendar svete familije za 1919. godinu, Čukovićev molitvenik Jezuš i Marija prelipa zrcala kršćanskoga žitka (1918.) te dva udžbenika, Početnica i čitanka za medjimurske pučke škole (1918.) i Meršićeva Slovnica hervatskoga jezika za selske škole.

${ }^{40}$ Kako bi se djelatnost Državnog odbora za propagandu na području hrvatskog nakladništva opisala u potpunosti, potrebna su daljnja istraživanja u Mađarskom državnom arhivu, pod fondom Ureda predsjednika Vlade (Miniszterelnökség) i Narodnosnog ministarstva (Nemzetiségi Minisztérium iratai).

${ }^{41}$ Béla Kun (Cehu Silvaniei/ROM, 1886. - Sibir?, 1939.), mađarski političar, tijekom Prvog svjetskog rata priključuje se boljševicima u Tomsku (1916.), sudjelovao u revoluciji 1917. U studenom 1918. se vraća u Mađarsku i sudjeluje u utemeljenju KP Mađarske. Pokreće partijske novine Vörös Újság (Crvene novine), a za vrijeme Mađarske Sovjetske Republike službeno je narodni komesar vanjskih poslova, a zapravo stvarni vođa države. Nakon poraza Mađarske Sovjetske Republike emigrira u Austriju, zatim odlazi u sovjetsku Rusiju, gdje sudjeluje u radu Kominterne. Stradao za vrijeme Staljinovih čistki. Izvor: „Kun, Béla“, u: Hrvatska enciklopedija, mrežno izdanje, pristup ostvaren: 31. III. 2019., http://www.enciklopedija.hr. 
prema djelatnosti jugoslavenske skupine u Mađarskoj. Budući da je odnos Antante prema formiranju Mađarske Sovjetske Republike od početaka bio negativan, u travnju 1919. češke i rumunjske snage dobile su zeleno svjetlo te je započela ofenziva na Mađarsku. Zahvaljujući brzoj mobilizaciji i iskusnom vodstvu, mađarska Crvena armija postigla je značajne vojne rezultate na sjevernoj bojišnici (današnja Slovačka). Unatoč ovim vojnim uspjesima do ljeta 1919. protiv vodstva Mađarske Sovjetske Republike okrenuo se značajan broj raznih političkih krugova i društvenih slojeva. Nakon sve teže unutrašnje gospodarske, društvene i vojne krize diktatura proletarijata je kapitulirala početkom kolovoza i predala vlast tzv. sindikalnoj vladi Gyule Peidla, koja je bila na vlasti tek nekoliko dana, do ulaska rumunjske vojske u Budimpeštu 4. i 5. kolovoza $1919 .{ }^{42}$

O položaju manjinskih zajednica za vrijeme Mađarske Sovjetske Republike slikovito govori podatak da su narodnosna pitanja bila povjerena samom Beli Kunu. ${ }^{43}$ Službena manjinska politika Mađarske Sovjetske Republike je bila u skladu s manjinskom politikom diktature proletarijata, odnosno na tragu učenja marksizma i lenjinizma, a u njihovom viđenju tzv. „manjinsko pitanje“ ne postoji, budući da će se s pobjedom svjetske revolucije proletera ono riješiti automatski. Jedan letak izdan na mađarskom jeziku u travnju 1919. govori o manjinskoj politici u ovo doba na sljedeći način:

„Mađarska Sovjetska Republika ne poznaje narodnosno pitanje (...) Rješavanje takozvanog narodnosnog pitanja je vrlo jednostavno. Stanovnike koji ne govore mađarski ${ }^{44}$ ne smatramo narodnostima, i ,pitanje" - više ne postoji. Samo je jedno pitanje ostalo neriješeno: uporaba jezika. Različitost materinskih jezika ne možemo, ali ni ne želimo ukinuti (...) Od sada više ne postoje poteškoće, nema više prigovora i proklete narodnosne nesuglasice će nestati bez traga." ${ }^{\text {"45 }}$

Glavnu ulogu u provođenju hrvatske manjinske politike u ovo vrijeme igrala je Južnoslavenska (ili Jugoslavenska) frakcija Socijalističko-komunističke federacije mađarskih internacionalista (mađ. Magyarországi Internacionalisták Szocialista-Kommunista Föderációja) ${ }^{46}$ Južnoslavenska frakcija je bila među najaktivnijim organizacijama Federacije, vršila je agitacijsku djelatnost,

${ }^{42}$ Kollega, Magyarország a XX. században.

43 Tilkovszky, Nemzetiségi politika Magyarországon a 20. században, 35.

${ }^{44} \mathrm{U}$ izvornom mađarskom obliku ovdje stoji izraz idegennyelvü.

${ }^{45}$ Hetés, A magyarországi forradalmak krónikája: 1918-1919, 183-184 (prijevod autora, S. B.).

${ }^{46}$ U Mađarskoj se do 1956. o razdoblju Mađarske Sovjetske Republike u stručnoj literaturi govori negativno, dok je u 60-im godinama među najpopularnijim temama, kako bi nakon demokratskih promjena bila slabo zastupljena u znanstvenim publikacijama. Viktor Szabó, A Magyarországi Tanácsköztársaság propagandája (Eger: Eszterházy Károly Főiskola, Történelemtudományi Doktori Iskola, 2016), 6-7. 
izdavala brojne letke, novine, pokrenula nastavu, ${ }^{47}$ organizirala skupove (prvenstveno u Budimpešti i okolici te u zapadnoj Mađarskoj ${ }^{48}$ i sl. Velik broj izdanja i aktivnosti u relativno kratkom roku (nešto više od 4 mjeseca) dokaz je već navedenoga, kako su se komunisti u ruskom egzilu iscrpno pripremili za preuzimanje vlasti i uvođenje vlastite uprave i politike. Određene nacionalne sekcije komunista se formiraju u Rusiji još tijekom 1918., prvenstveno od ratnih zarobljenika. Tako se formirala i mađarska sekcija, čije se članstvo sastojalo ne samo od mađarskih, već i južnoslavenskih članova, kao što su Ivan Matuzović, ${ }^{49}$ Lazar Vukičević, ${ }^{50}$ Franc Drobnik..$^{51}$ Budući da je osim Sovjetskog Saveza diktatura proletarijata privremeno zavladala samo u Mađarskoj, Budimpešta je bila svojevrsni centar internacionalista preko kojeg se pripremala komunistička revolucija u zemljama regije, odnosno preko kojeg su komunisti u ovim zemljama držali kontakt s Moskvom..$^{22}$ Dokaz toga je i budimpeštanski sastanak Matuzovića i Drobnika s Filipom Filipovićem ${ }^{53}$ predvodnikom jugoslavenskog komu-

${ }^{47}$ Prema Belleru, Južnoslavenska frakcija je u kratkom roku uvela nastavu na jeziku manjina (prvenstveno za Srbe), posebno ističe mjesta: Sentandriju (mađ. Szentendre) i Čobanac (mađ. Csobánka). Beller, „A Magyar Népköztársaság és a Tanácsköztársaság nemzetiségi kultúrpolitikája", 11. Najveća prepreka pokretanju nastave na manjinskom jeziku je bio nedostatak nastavnika. László Kövágó, Internacionalisták a Tanácsköztársaságért (Budapest: Kossuth Könyvkiadó, 1969), 85.

${ }^{48}$ Kővágó, Internacionalisták a Tanácsköztársaságért, 83.

${ }^{49}$ Ivan Matuzović (1886.-1938.) je porijeklom iz Bosne, služio je u Austro-ugarskoj vojsci dok nije zarobljen u Rusiji. Od jeseni 1918. djelovao je u Mađarskoj i pripremao socijalističku revoluciju na južnoslavenskim područjima (vrbovanje vojnika, organiziranje obrambene linije). Nakon pada Mađarske Sovjetske Republike boravio je u Beču, Kraljevini SHS, a na kraju u Sovjetskom Savezu, gdje je 1938. preminuo kao žrtva Staljinove čistke. Kővágó, Internacionalisták a Tanácsköztársaságért, 29.

${ }^{50}$ Lazar Vukičević (1887.-1941.), tipografski radnik iz Sombora, prije Prvog svjetskog rata član Srpsko-bunjevačkog agitacijskog odbora Mađarske socijaldemokratske stranke, za vrijeme rata u Rusiji predsjednik jugoslavenske sekcije komunista, bio je među osnivačima Jugoslavenskog komunističkog saveza „Pelagić“. Zbog djelatnosti u Kraljevini SHS za vrijeme Mađarske Sovjetske Republike boravi u Mađarskoj, a nakon toga se vraća u Kraljevinu SHS. Likvidirao ga je Gestapo 1941. Kővágó, Internacionalisták a Tanácsköztársaságért, 30.

${ }^{51}$ Kővágó, Internacionalisták a Tanácsköztársaságért, 28.

${ }^{52}$ Prema Kővágóu, iz Moskve su kuriri svaki tjedan putovali u Budimpeštu, zatim u Kraljevinu SHS te nazad. Iz Moskve bi sa sobom uvijek donijeli novine i propagandne letke koje bi u Budimpešti pretiskali i poslali dalje, u Kraljevinu SHS. Kővágó, Internacionalisták a Tanácsköztársaságért, 41.

${ }^{53}$ Revolucionar Filip Filipović (1878.-1938.) je rođen u Čačku, studirao je matematiku u Petrogradu, gdje se priključuje socijaldemokratima. 1912. se vraća u Beograd i započinje svoju djelatnost na području organiziranja komunističkih grupa u zemljama srednje i jugoistočne Europe. Obavlja visoke dužnosti u KPJ i Kominterni. Preminuo je u Rusiji 1938. u staljinskim čistkama. Velimir Visković (ur.), Krležijana, mrežno izdanje (Zagreb: Leksikografski zavod Miroslav Krleža), pristup ostvaren: 16. 05. 2016. http://krlezijana.lzmk.hr/. 
nističkog pokreta. ${ }^{54}$ Prema Kővágóu, jugoslavenska grupa u Mađarskoj djeluje već od prosinca 1918., ${ }^{55}$ a o jednome od prvih zasjedanja skupine znamo da se dogodilo 6. siječnja 1919. u jednoj budimskoj kavani. Južnoslavenska skupina u Budimpešti je djelovala u VI. kvartu, u Ulici Rózsa br. 61 (tzv. Dom MarksLenin). Osim bivših ruskih zarobljenika, u radu komunističkih organizacija u Mađarskoj u manjem broju su sudjelovali i „domaći“ komunisti (s područja današnje Mađarske) ${ }^{56}$ Ipak, prvenstveni zadatak skupine nije bila propaganda među hrvatskim, srpskim i slovenskim zajednicama na području Mađarske, već pripremanje socijalističke revolucije u centralnim područjima Kraljevstva SHS. U suradnji s raznim državnim službama i vojskom razradili su komunikacijsku mrežu koja je propagandne materijale prenijela preko granica i putem agenata proširila u unutrašnjost države.

S našeg aspekta je posebno važno da je jugoslavenska skupina imala vrlo aktivnu izdavačku djelatnost. Za svoju propagandnu djelatnost izdavala je brojne letke i posebne novine pod naslovom Crvena zastava ${ }^{57}$ u Budimpešti. List je u početku izlazio u velikoj nakladi od 25 tisuća primjeraka, što se postupno smanjilo do kolovoza. ${ }^{58}$ Trebao je izlaziti dva puta tjedno (srijedom i subotom), jedanput ćirilicom, a drugi put latinicom. ${ }^{59} \mathrm{U}$ jednom izvoru se navodi da prvi broj izlazi 9. travnja 1919., a zadnji 1 . kolovoza $1919 .{ }^{60} \mathrm{U}$ zbirci Državne knjižnice Széchenyi u Budimpešti sačuvan je prvi broj (ćirilicom), ali s nadnevkom 5. travnja 1919., slijedi broj od 19. travnja (ponovo ćirilicom), a sljedeći broj iz zbirke knjižnice izlazi 1. svibnja 1919., prvi put s oznakom broja (br. 5.), kao prvi broj latinicom. S istim nadnevkom izlazi i broj na ćirilici, ali kao poseban broj (br. 6.). Prateći numeraciju, vidimo da su nakon toga u Budimpešti sačuvani svi brojevi do 18., koji izlazi 26. srpnja 1919. ${ }^{61}$ Prema kasnijim brojevima možemo zaključiti kako je list izlazio

\footnotetext{
${ }^{54}$ Kővágó, Internacionalisták a Tanácsköztársaságért, 38.

${ }^{55}$ Kővágó, Internacionalisták a Tanácsköztársaságért, 39.

${ }^{56}$ Kővágó, Internacionalisták a Tanácsköztársaságért, 49.

${ }^{57}$ Prema online katalogu zagrebačke Nacionalne i sveučilišne knjižnice, u Zagrebu pod istim nazivom izlazi list u razdoblju od 1919. do 1920. i od 1925. do 1929. Pretpostavljamo da je tijekom 1919. bilo uže suradnje između listova u Zagrebu i Budimpešti, a postoji mogućnost da su u kasnijem razdoblju u pripremanju zagrebačkih brojeva surađivali i suradnici iz Budimpešte.

58 Josip I. Vidmar, „Prilozi građi za historiju radničkog pokreta i KPJ 1919. godine“, Arhivski vjesnik 2 (1959), 218.

59 „Crvena zastava“, Crvena zastava (Budimpešta), 5. IV. 1919., 1. Usporedbom brojeva tiskanih latinicom i ćirilicom možemo ustanoviti da nije riječ o jednostavnoj transliteraciji, već se ćirilična izdanja pišu tadašnjim srpskim, a latinična tadašnjim hrvatskim pravopisom.

${ }^{60}$ Vidmar, „Prilozi građi““, 218.

${ }^{61}$ Ako je numeracija točna, možemo zaključiti da iz fonda Državne knjižnice Széchenyi nedostaju tri broja, dva između 5. travnja i 1. svibnja te zadnji broj s nadnevkom od 1. kolovoza
} 
neredovito, većinom tjedno jedanput, pretežito na četiri, a ponekada i na šest ili osam stranica. U početku se tiskaju posebni brojevi na latinici i ćirilici, a od 7. broja (8. svibnja 1919.) u istom broju čitamo tekstove na latinici i ćirilici. Adresa uredništva je smještena na budimpeštanskoj adresi Jugoslavenske skupine (VI. kvart, Ulica Rózsa 61). Glavni urednik je bio Lazar Vukičević, za hrvatsko izdanje je bio odgovoran Franjo Ljuština (i pod imenom Kalić; prema Berti Kraus, tajnici jugoslavenske grupe u Budimpešti), ${ }^{62}$ a član uredništva je još bio i student Ante Ciliga. ${ }^{63}$ Iz zapisnika sa saslušanja Svetozara Mošorinskog, tajnika budimpeštanske južnoslavenske grupe, ${ }^{64}$ saznajemo kako je Crvena zastava tiskana u tiskari „Palas“, ${ }^{65}$ i to prema nalogu samog Bele Kuna ili Ernőa Póra, ${ }^{66}$ te kako je velik dio tekstova preveden s mađarskog jezika jer su imali prevoditelje, a surađivali su i s drugim državnim uredima zbog prevođenja. Pretplatnika je bilo vrlo malo (prema Mošorinskom, tek 180) i svi su bili članovi partije. ${ }^{67} \mathrm{O}$ distribuciji novina navodi sljedeće: u Budimpešti i okolici je prodavano oko 500 komada, oko 1000 je poslano u zapadnu Mađarsku (okolica Sambotela, mađ. Szombathely), a skoro sve ostalo je poslano na područje Kraljevstva SHS pomoću agenata u pograničnom području: Kiskunhalas, Kaposvár, Komló, Gyékényes. ${ }^{68}$ Preko Komlóa je velik dio novina dospio u Pečuh, naročito putem rudara, kod dr. Hajdua, ${ }^{69}$ a dalje

1919., ako možemo vjerovati izvoru u bilješci br. 52.

${ }^{62}$ Vidmar, „Prilozi građi“, 206. Ime Ljuštine se spominje u ovim godinama u policijskim izvješćima o uličnim prosvjedima i okupljanjima u Zagrebu na kojima je on propagirao komunizam (Vidmar, „Prilozi građi“, 53-54). Rođen je u Vinkovcima 1894., već prije Prvog svjetskog rata se priključio lijevim grupacijama i postupno se radikalizirao do kraja rata. Za vrijeme rata i u poratnim godinama pod prismotrom je policije (Vidmar, „Prilozi građi“, 62-63).

${ }^{63}$ Kővágó, Internacionalisták a Tanácsköztársaságért, 82.

${ }^{64}$ Vidmar, „Prilozi građi“.

${ }^{65}$ Tiskara Pallas (Pallas Irodalmi és Nyomdai Rt.) jedna je od najznačajnijih i najvećih mađarskih tiskara koja djeluje od 1884. s promijenjenim nazivom. Judit Sebesi, „N. Pataki Márta: A Kossuth Nyomda története 1884-1984“, Magyar Grafika 29 (1985), br. 1-2: 94-99.

${ }^{66}$ Ernő Pór (Zvolen/SK, 1888. - Sovjetski Savez, 1939.). Od 1905. uključuje se u radničke pokrete, krajem Prvog svjetskog rata sudjeluje u utemeljenju Mađarske Komunističke Partije, za vrijeme Mađarske Sovjetske Republike na čelu je Ureda za propagandu, pored Bele Kuna najutjecajnija osoba u ovo doba. Nakon pada boljševika emigrira u Beč, zatim u Prag, od 1922. živi u Sovjetskom Savezu. Preminuo je od posljedica Staljinovih čistki (Kenyeres, Magyar életrajzi lexikon).

${ }^{67}$ Vidmar, „Prilozi građi“, 218.

${ }^{68}$ Isto. Za vrijeme Mađarske Sovjetske Republike južni dio Mađarske je okupiran sa strane vojske Kraljevstva SHS, a navedeni gradovi su bili smješteni uz samu granicu.

${ }^{69}$ Vjerojatno je riječ o Gyuli Hajduu (Somogyszil, 1886. - Budimpešta, 1973.). Pravnik, doktor prava, školovao se u Pečuhu, gdje je imao odvjetnički ured. Već od početka 20. stoljeća aktivno sudjeluje u aktivnostima socijaldemokratske stranke, za vrijeme Mađarske Sovjetske Republike surađuje s boljševicima i mađarskom Crvenom armijom. 1919. emigrira u Italiju 
su išle u Beograd, posredovanjem agenta Save Mirkovića u Pečuhu. ${ }^{70}$ Preko Gyékényesa su se novine plasirale u Zagreb i Sarajevo, uz logističku pomoć crvenoarmejaca i krijumčara. ${ }^{71}$

Na sličan način je jugoslavenska grupa izrađivala i slala letke na područje Kraljevstva SHS. Mošorinski u citiranom zapisniku navodi da su sastavili 22 "listića“" latinicom i ćirilicom i 4 brošure..$^{72} \mathrm{O}$ takvim sitnim izdanjima svjedoči i Crvena zastava u svom 5. broju od 1. svibnja 1919. na prvoj stranici kada u pozivu na povorku navodi da ,će se prodavati dva prvomajska lista i tri male brošure: 1. Prvi Maj 1919.; 2. Kome pripada zemlja?; 3. Tko su boljševici?““. Dodatno se navodi još da su ova izdanja tiskana „u oba pisma (latinicom i ćirilicom) ${ }^{4}{ }^{73}$ Osim jugoslavenske grupe, letke i brošure je izdavalo i mađarsko „Prosvetno odeljenje“ (Ministarstvo obrazovanja) na jeziku južnoslavenskih manjina (prema Mošorinskom, „7 brošura i 16 ili 17 letećih listića“). ${ }^{74}$ Najviše listića je također išlo preko Komlóa, tvrdi Mošorinski, ponekada i pola vagona, tj. oko 100 tisuća primjeraka. Pretpostavljamo da su ovi listići preko Pečuha preneseni u središnja područja Kraljevstva SHS, slično Crvenoj zastavi. ${ }^{75}$ Zahvaljujući bibliografiji koja sakuplja letke izdane za vrijeme Mađarske Sovjetske Republike, ${ }^{76}$ saznajemo kako je na srpskom i hrvatskom jeziku ${ }^{77}$ izdano 74 letka, dakle puno više od onoga što je Mošorinski tvrdio. Letci su većinom izdani na jednoj ili dvije, rijetko i više stranica, na srpskom, hrvatskom, a ponekada i na dijalektima (bunjevački). Prema sadržaju mogu se podijeliti u nekoliko skupina: poziv u (mađarsku) Crvenu armiju, pobjeda revolucije (u Mađarskoj), prednosti novog društvenog poretka itd. Posebno možemo izdvojiti letke u velikom broju koji su sastavljeni za stanovništvo

pa se 1920. vraća u Pečuh, kada je interniran u Srbiju. Srpska uprava ga nakon pola godine protjeruje i on odlazi u Austriju i Francusku, gdje također sudjeluje u ljevičarskim pokretima. 1945. se vraća u Mađarsku i zauzima visoke političke i akademske položaje do svoje smrti (Kenyeres, Magyar életrajzi lexikon).

${ }^{70}$ Kővágó, Internacionalisták a Tanácsköztársaságért, 89.

${ }^{71}$ Vidmar, „Prilozi građi“", 218-219.

72 Vidmar, „Prilozi građi“, 218.

73 „Drugovi i drugarice!“, Crvena zastava, 1. V. 1919., 1.

74 Vidmar, „Prilozi građi“, 218.

${ }^{75} \mathrm{O}$ tome svjedoči izvješće Državnog odvjetništva o istrazi koja je razotkrila mrežu osječkih komunista. Uhvaćeni su krajem travnja kada su po gradu lijepili letke, od kojih su mnogi tiskani vjerojatno u Mađarskoj, a kod članova organizacije pronađena je i Crvena zastava (Vidmar, „Prilozi građi“, 111-120).

${ }^{76}$ Andor Tiszay et al. (ur.), A Magyar Tanácsköztársaság röplapjai: bibliográfia és dokumentumgyüjtemény (Budapest: Fővárosi Szabó Ervin Könyvtár, OSZK, 1959).

${ }^{77}$ Mada je tema ovoga rada pregled hrvatskog nakladništva, u naš korpus ulaze i izdanja koja su izdana na srpskom jeziku, budući da su i ona često namijenjena i distribuirana među Hrvatima u Mađarskoj sve do početka 1990-tih godina. 
Kraljevstva SHS. ${ }^{78}$ Uspoređujući ova sitna izdanja na raznim jezicima, primjećuje se isti sadržaj, što upućuje je na to da je vjerojatno riječ o prijevodima s mađarskog ili ruskog na jezik raznih narodnosti.

S aspekta publike, spomenuto je već kako je nakladnička djelatnost frakcije usmjerena i prema „domaćim“ južnoslavenskim narodnostima (Srbi, Hrvati i Slovenci), ali da je dominirala propaganda prema Kraljevini SHS, gdje se pripremao prevrat, slično događajima u Mađarskoj. O ciljanoj publici govori i Mošorinski kada tvrdi sljedeće:

„Često puta među nama je bila raspra [rasprava, op. a.] oko načina i pravca cele propagande. Prvi broj lista [Crvene zastave, op. a.] sadržavao je propagandu za Jugoslavenski živalj u Mađarskoj, ali Matuzović, Ljuština, Hegyi Josip i Vukičević (lažno ime Nikola Ilić) bili su zato da se radi samo na propagandi u Jugoslaviji, veleći, da je to najsnažnija stvar da se u Jugoslaviji postigne uspeh. Oni su ovo mišljenje zastupali energično i odma je list počeo pisati samo za Jugoslaviju. “"79

Budući da su vodeći aktivisti jugoslavenske grupe u Budimpešti bili s područja tadašnjeg Kraljevstva SHS, vjerojatno nisu imali uvida u točno stanje i položaj svojih zajednica na području današnje Mađarske ${ }^{80}$ ili su smatrali da zbog visokog stupnja integriranosti ovih zajednica u mađarsko društvo njima nije potrebna posebna ,južnoslavenska“ propaganda, već je dovoljna ona mađarska. Bez obzira na to, jedan dio ovih izdanja je zasigurno došao i do Hrvata koji žive na prostoru današnje Mađarske, stoga i ovu građu možemo smatrati dijelom cjelokupne hrvatske pisane baštine u Mađarskoj.

\section{Nakladništvo za Hrvate za vrijeme srpske okupacije južne Mađarske}

U Beogradu je 13. studenog 1918. potpisana vojna konvencija između Antante i Mađarske koja je omogućila srpskoj vojsci da okupira južne dijelo-

78 „POSLANICA ROBOVIMA ZEMLJE! Braćo seljaci! S izmorenim rukama, u znoju svoga lica stvarate kruh za gazde i gospodu..." (Tiszay, A Magyar Tanácsköztársaság röplapjai, 186).

${ }^{79}$ Vidmar, „Prilozi građi“, 219.

${ }^{80}$ Spomenutu tvrdnju djelomice potvrđuje ponašanje diplomacije Kraljevine SHS za vrijeme poslijeratnih mirovnih pregovora u Parizu tijekom 1919. Naime, početkom konferencije Beograd nije zatražio okupirane teritorije današnje južne Mađarske stoga što o etničkom sastavu stanovništva, kao ključnom principu za vrijeme konferencije, nije imao informacija. Pretpostavljalo se da osim malobrojnog srpskog stanovništva na ovom području pretežito žive Mađari, pa se nakon saznanja o relativno velikom broju Hrvata i Srba te provedenog popisa stanovništva 1919. politika predstavnika Kraljevine SHS promijenila. Vidi: Árpád Hornyák, „A szerb megszállás Baranyában“, História 32 (2010), 9-10: 49-51. 
ve Mađarske, dio Baranje i Bačke. ${ }^{81}$ Prve postrojbe su ubrzo, već dan nakon potpisivanja sporazuma, stigle u Pečuh, što upućuje na to da je okupacija bila unaprijed pripremljena. Unatoč tome, delegacija Kraljevstva SHS na mirovnoj konferenciji u Parizu nije zatražila pripajanje Pečuha i Baranje u početku (tijekom veljače 1919.), već tek onda kada mirovna konferencija donosi službenu odluku o granicama, tijekom proljeća i ljeta 1919. ${ }^{82}$ Tijekom opsade, koja je trajala gotovo 33 mjeseca (13. studenog 1918. - 20. kolovoza 1921.), srpski vojni i civilni dužnosnici su vršili aktivnu propagandu, a glavna meta takve djelatnosti je bilo srpsko i hrvatsko stanovništvo na okupiranom području. U tu svrhu pokreću se i novine pod naslovom Baranjski glasnik, koje izlaze od 30. listopada 1919. do 14. kolovoza 1921. na srpskom jeziku. Pored toga izlaze Službene novine Baranjske županije (mađ. Baranya Vármegye Hivatalos Lapja) ${ }^{83}$ u Pečuhu, od 5. lipnja 1919. dvojezično (mađarski i srpski), sve do 18. kolovoza 1921. Za vrijeme srpske okupacije izlazile su dvoje „službene" novine Baranjske županije; spomenute u Pečuhu pod uredništvom srpskih dužnosnika, a druge u naselju Sásdu, pod mađarskom upravom, samo na mađarskom jeziku ${ }^{84} \mathrm{U}$ pečuškim službenim novinama za vrijeme okupacije objavljene su razne uredbe, obavijesti župana i županijskih vlasti. Za vrijeme dvojezične objave stranice su bile raspoređene u dva stupca, $u$ jednom je bio naveden mađarski tekst, $\mathrm{u}$ drugom prijevod na srpski. Novine su tiskane latinicom.

Dok su službene novine donosile puke upravne obavijesti, u slučaju $B a-$ ranjskog glasnika možemo govoriti o štivu koje je itekako bilo usmjereno prema širem srpskom i hrvatskom stanovništvu na okupiranom području. ${ }^{85}$ Mada je broj znanstvenih radova ili publikacija koje bi se konkretno bavile Baranjskim glasnikom vrlo skroman, o samoj djelatnosti srpskih dužnosnika u Pečuhu postoje informacije zahvaljujući memoarima Milana Glibonjskog,

\footnotetext{
${ }^{81}$ Árpád Hornyák, „Impériumváltás(ok) Pécsen szerb szemmel“, Limes 2005/1, 21.

${ }^{82}$ Vidi prethodnu bilješku.

${ }^{83}$ List je u potpunosti dostupan putem online baze podataka Arcanum (www.arcanum.hu).

${ }^{84}$ Zoltán Iglói (ur.), Pécs-Baranya sajtójának bibliográfiája 1918-1921. (Pécs: MSZMP Baranya megyei Bizottsága, Propaganda és Művelődési Osztálya, 1966), 19.

${ }^{85}$ O čitanosti Baranjskog glasnika među Hrvatima u Baranji govori nam jedan izvor koji obrađuje izvještaje vladinog povjerenika za Južne Slavene u Mađarskoj, koji je nakon povlačenja vojske Kraljevine SHS obišao hrvatska naselja. U njemu vladin povjerenik József Margitai u slučaju naselja Németi (danas dio naselja Szalánta), koje se nalazi nedaleko od Pečuha, navodi da su Srbi za vrijeme okupacije slali list na materinskom jeziku iz Pečuha. Ferenc Tegzes, „A miniszterelnökség délszláv szakreferensének jelentései a baranyai délszlávokról az 1920-as évek első felében“, u: Baranyai helytörténetírás 1978. (Pécs: Baranya megyei Levéltár, 1979), 485. Mada se ne spominje doslovno ime lista, pretpostavljamo da je riječ o Baranjskom glasniku, budući da u to doba nije bilo drugog periodičnog izdanja na hrvatskom ili srpskom jeziku u Pečuhu.
} 
koji su izdani 2009. u Beogradu ${ }^{86}$ te u prijevodu na mađarski 2006. u Pečuhu. ${ }^{87}$ Za vrijeme srpske okupacije Glibonjski je imenovan za voditelja baranjskog Ureda za tisak, uređivao je Baranjski glasnik te bio autor mnogih napisa u njemu. Osim toga, bio je aktivan organizator raznih okupljanja, masovnih mitinga (s 5-6 tisuća sudionika) na kojima se zahtijevalo pripajanje okupiranog područja Kraljevstvu SHS. ${ }^{88}$

Kako je navedeno na naslovnicama Baranjskog glasnika, ${ }^{89}$ uredništvo je bilo smješteno u Pečuhu, u Ulici Papnövelde 3. Pored Glibonjskog, u uređivanju novina je sudjelovao i dr. Milan Vakanjac, koji je do 25. prosinca 1919. bio odgovorni urednik, a nakon toga jedini urednik novina je Glibonjski. Osim njih, za novine su pisali i Vladislav Pandurović, ${ }^{90}$ Vojislav Djurdjević, Jure Folnegović ${ }^{11}$ i dr. Tiskane su u pečuškoj tiskari Dunántúl (Dunántúl Könyvkiadó és Nyomda Rt.), ${ }^{92}$ a Glibonjski u memoarima navodi da je list financiran iz Beograda. ${ }^{93}$ Glasnik je trebao izlaziti svakoga četvrtka, ali zbog raznih okolnosti, čestih štrajkova, nestašice papira i drugih sirovina, tiskanje nije bilo kontinuirano. Od prvog do zadnjeg broja tiskao se na latinici, premda u početku nije bio takav plan urednika. U prvom broju objavljena je kraća obavijest pod naslovom „Srbima čitaocima“ u kojoj stoji da će list „možda već u skoro vreme početi izlaziti i ćirilicom“ te da će vjerojatno „kroz kratko vreme doći

${ }^{86}$ Milan Glibonjski, Baranja (1918-1923): sećanja (Beograd: Čigoja; Istorijski institut, 2009).

${ }^{87}$ Milan Glibonjski, Pécs szerb megszállása egy szerb újságíró szemével (Pécs: Pécs Története Alapítvány, 2006), preveo Árpád Hornyák.

${ }^{88}$ Glibonjski, Pécs szerb megszállása egy szerb újságíró szemével, 20.

${ }^{89}$ Svi brojevi Baranjskog glasnika dostupni su u Arhivu Baranjske županije u Pečuhu (Magyar Nemzeti Levéltár Baranya Megyei Levéltára).

${ }^{90}$ Dr. Vladislav Pandurović je rođen u baranjskom Šiklošu (mađ. Siklós) 1876. Školovao se u Pečuhu (niža gimnazija) i Budimpešti (kadetska škola). Do 1911. nastavnik je kadetske škole u Pečuhu. Naknadno je položio gimnazijsku maturu u Pečuhu te studij prava u Budimpešti, Pečuhu i Cluju. Za vrijeme srpske okupacije imenovan za župana i povjerenika Baranje i grada Pečuha. Nakon povlačenja radi kao pravnik u Brčkom. D. P., „Pandurović Vladislav Dr.“, u: Narodna enciklopedija srpsko-hrvatsko-slovenačka, knj. 3 (Zagreb: Bibliografski zavod, 1928), 340.

${ }^{91}$ O Folnegoviću znamo da je bio katolički svećenik, jedno vrijeme župnik u Vršendi, te da se za vrijeme okupacije zalagao za priključenje Baranje Kraljevini SHS (Glibonjski, Pécs szerb megszállása egy szerb újságíró szemével, 128). U tu svrhu vršio je agitaciju među lokalnim stanovništvom, točnije u naseljima Semelj (mađ. Szemely), Birjan (mađ. Birján) i Lotar (mađ. Lothárd), među kojima je došlo i do sukoba u navedenom pitanju (Tegzes, „A miniszterelnökség délszláv szakreferensének jelentései a baranyai délszlávokról az 1920-as évek első felében“, 498).

${ }^{92}$ Spomenuta tiskara nasljednik je pečuške biskupske tiskare Lyceum, utemeljene 1836., a prethodnik tiskare Szikra, koja je nakon nacionalizacije poslije Drugog svjetskog rata dugo godina bila najveća tiskara u Pečuhu. Károly Borsy, „A pécsi nyomdászat múltjáról“, Pécsi Szemle 1 (1998), br. 1-2: 52-53.

${ }^{93}$ Glibonjski, Pécs szerb megszállása egy szerb újságíró szemével, 57-58. 
i do ćirilnih slova“" ${ }^{94}$ Prema tome, u Pečuhu u godinama nakon Prvog svjetskog rata nije bilo ni u jednoj tiskari ćiriličnih slova, a nisu ih mogli nabaviti ni s prostora Kraljevstva SHS sve do povlačenja srpskih postrojbi. Osim toga, pretpostavljamo da sami tiskari nisu govorili ni jedan južnoslavenski jezik, što se daje zaključiti po brojnim slovnim pogreškama u skoro svakom napisu.

Jedan od glavnih zadataka Baranjskog glasnika je bio pridobiti lokalno hrvatsko i srpsko stanovništvo na okupiranom području za ,jugoslavensku ideju“. Dok u slučaju Srba većih prepreka nije bilo, situacija sa Šokcima ${ }^{95}$ nije bila toliko jednostavna. I sam Glibonjski u memoarima navodi kako je već prilikom svog boravka na ovim prostorima Baranje $1910 .{ }^{96}$ ustanovio da su se Šokci „,vrlo pomađarili“, dok su Srbi uspjeli očuvati svoj identitet zahvaljujući crkvi i učiteljima, ${ }^{97}$ koji su također djelovali u sklopu Pravoslavne crkve. U tom duhu nastaje tekst u Baranjskom glasniku pod naslovom ,Šokci“ “98 u kojemu uredništvo odmah daje na znanje da su i oni, tj. Šokci, dio svekolikoga slavenstva, obitelji Srba, Hrvata i Slovenaca, mada su bili izloženi jakoj asimilaciji. ${ }^{99}$ O novom jugoslavenskom konceptu koji bi trebali prigrliti i Šokci objavljen je duži tekst, vjerojatno Vojislava Djurdjevića. ${ }^{100}$ Naslovljen je „,Srbima!“, a u njemu se govori o novoj državi i nacionalnom konceptu nove države. Mada se na određenim mjestima govori kako se stvara nova Velika Srbija, autor ipak obrazlaže da to ne može biti takva država kakvu su prije sanjali, ali da će u njoj ipak Srbi biti „prvi“ narod, koji je najzaslužniji za stvaranje nove države. ${ }^{101} \mathrm{O}$ odnosu Šokaca i Srba piše i urednik Milan Glibonjski u tek-

94 „Srbima čitaocima“, Baranjski glasnik (Pečuh), 30. X. 1919., 4.

${ }_{95}$ Glibonjski u svojim memoarima i u Baranjskom glasniku nikada ne spominje Hrvate na okupiranom području, već govori o Šokcima ili rijetko o Bošnjacima u okolici Pečuha. Pri tome nije jasno je li svjesno ignorirao ostale hrvatske subetničke skupine na okupiranom području, na primjer Hrvate uz rijeku Dravu, Bunjevce u Bačkoj, ili zbog neupućenosti nije poznavao određene regionalne razlike.

${ }^{96}$ Glibonjski je u ovo doba boravio u ovom dijelu Baranje i bavio se etnografskim istraživanjima za srpskog etnografa Jovana Cvijića. Glibonjski, Pécs szerb megszállása egy szerb újságíró szemével, 7.

${ }_{97}$ Glibonjski, Pécs szerb megszállása egy szerb újságíró szemével, 54.

98 „Šokci“, Baranjski glasnik, 6. XI. 1919., 1.

${ }^{99}$ Iz ovoga napisa se ne može jasno saznati smatra li autor Šokce posebnim narodom ili subetničkom zajednicom jedne od navedenih nacionalnih zajednica, ali je jasno da Šokce nikako ne povezuje s Hrvatima. Međutim, u određenim rečenicama povezuje ih sa srpskom zajednicom: „Sve se pokušalo, samo da bi mogli iščupati vaše srpsko, vaše slavensko srce i mesto njega usaditi drugo, njihovo, tudjinsko.“"

${ }^{100}$ V. Gj., „Srbima!“, Baranjski glasnik, 20. XI. 1919., 2-3.

${ }^{101}$ U ovom napisu čitamo i konstatacije kako je Srbiji svakako potreban izlaz na more te da je bez Hrvatske i Slovenije Srbija Balkan, a s njima je povezana s Europom. 
stu pod naslovom „Šokci i Srbi““ ${ }^{102}$ Autor pretpostavlja da se šokačko-srpska integracija može provesti bez ikakvih prepreka, te navodi da se svi prijašnji nesporazumi trebaju zaboraviti kako bi se krenulo u izgradnju nove zajednice.

Jedno od češćih imena na stranicama Baranjskog glasnika je ime dr. Tamása Prakatura, ${ }^{103}$ povjerenika mađarske vlade za Baranju, koga Glibonjski često spominje u negativnom kontekstu na stranicama glasnika i u svojim memoarima također. Pod naslovom „Jedno pismo i moj odgovor na njega“104 na dvije stranice Glibonjski donosi pismo dr. Prakatura koje je on (Prakatur) uputio Svetislavu Rajiću, tadašnjem baranjskom podžupanu, u kojemu Prakatur optužuje Baranjski glasnik za poticanje mržnje i klevetu. Prakatur navodi da to ne bi trebalo biti u interesu srpske uprave, da se trebaju truditi oko mirne reintegracije, te kao vladin povjerenik za Baranju garantira da se Srbi koji će ostati na području Mađarske nakon evakuacije srpske vojske neće diskriminirati ni na koji način zbog etničkih razloga. U svom odgovoru Glibonjski sumnja u Prakaturove garancije, budući da iz Mađarske neprestano stižu vijesti o Horthyjevim odmazdama (misleći na tzv. „,bijeli teror“, mađ., ,fehér terror”) ${ }^{105}$ te da je Prakatur „odnarodjen Šokac“ i ,služi verno i odano Madjare i njihove interese“. Već u broju od 6. svibnja 1920. list donosi vijest o interniranju dr. Prakatura u Valjevo zbog optužbi da kolaborira s Mađarima. ${ }^{106}$ Ovdje Glibonjski piše i o tome da je još 1918. potražio Prakatura i zamolio ga za suradnju, što je on i prihvatio, ali samo u tajnosti. Činjenica da Prakatur nije postao suradnikom srpske propagande, već je imenovan povjerenikom mađarske vlade za Baranju, kod Glibonjskog je izazvala duboko gnušanje prema njemu, što se jasno očituje iz njegovih napisa. ${ }^{107}$

Pored ove teme, u glasniku se često bave i evakuacijom, naročito od proljeća 1920., a jedno od najvažnijih pitanja je mogućnost ostajanja u Mađarskoj

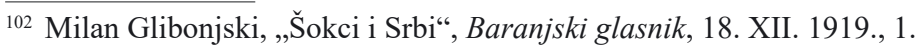

${ }^{103}$ Dr. Tamás Prakatur (Duboševica/Dályok, 1879. - Mohač/Mohács, 1929.), rodio se u šokačkoj obitelji, od 1906. radi kao odvjetnik u Mohaču, stekao je veliki ugled među Šokcima. 1920. imenovan je za povjerenika mađarske vlade za Baranju, zastupnik je mađarskog parlamenta tijekom 1920-ih godina te utemeljitelj Šokačko-mađarske čitaonice u Mohaču. Miklós Füzes (ur.), Nemzetiségi ügyek dokumentumai Baranyában 1923-1938. (Pécs: Baranya Megyei Levéltár, 2001), 323.

${ }^{104}$ Milan Glibonjski, „Jedno pismo i moj odgovor na njega“, Baranjski glasnik, 1. V. 1920., 1-2.

${ }^{105}$ Prema izvorima, tijekom čistki pod vodstvom Horthyjevih vojnih postrojbi do jeseni 1920. ubijeno je više tisuća komunista koji su bili aktivni za vrijeme Mađarske Sovjetske Republike (Kollega, Magyarország a XX. században).

${ }^{106}$ Milan Glibonjski, „Interniranje dr.-a Prakatura“, Baranjski glasnik, 6. V. 1920., 3.

${ }^{107}$ Da Prakatur nije bio dugo u internaciji, potvrđuje kasniji napis u Baranjskom glasniku („Dr. Prakatur kod kuće“, Baranjski glasnik, 15. VI. 1920., 4). 
ili optiranje za Kraljevstvo SHS. ${ }^{108}$ Novine nude prostor i književnim sadržajima. U posebnim rubrikama donose se autorske pjesme i prozni oblici u nastavcima, usmene pripovijetke i predaje, prvenstveno iz srpskih naselja ili od srpskih autora. ${ }^{109}$ Redovito se u svakom broju donose rubrike Vesti iz Kraljevstva SHS i Iz mesta i okolice. Iz ove druge saznajemo detalje o događajima na okupiranom području, što može biti korisno s aspekta zavičajne povijesti. Kod prvih brojeva primjećujemo velik broj oglasa (na srpskom jeziku) ugostiteljskih objekata, banaka, trgovina i raznih usluga iz Pečuha i okolice, pa čak i iz Beograda, koji postupno nestaju tijekom 1920. godine.

$\mathrm{S}$ aspekta istraživanja nakladništva posebno bismo istaknuli sadržaje u Baranjskom glasniku koji se bave s nakladništvom. Prvi takav sadržaj izlazi u broju od 18. srpnja 1920. u obliku kraće vijesti u kojoj se spominje da je jedan Šokac iz sela Šaroša (mađ. Magyarsarlós) na njivi našao propagandne letke s pozivom Bunjevcima i Šokcima s likom guvernera Miklósa Horthyja te jedan broj „bunjevačkih novina”. ${ }^{110}$ Autor navodi kako će se o ovim sadržajima detaljnije govoriti u idućem broju. Tako je u broju od 25. srpnja 1920. godine objavljen tekst Jurja Folnegovića pod naslovom Naša Domovina. ${ }^{111}$ Autor navodi kako se spomenuti list izdaje u Budimpešti na hrvatskom jeziku i putem tajnih agenata ili zrakoplova plasira se na okupirano područje. Folnegović opisuje sadržaj koji propagira Mađarsku, garantira manjinska prava u novoj državi, dok sumnja $u$ ista prava za narodnosti na okupiranom području. Navodi da je list namijenjen „da ga čitaju Hrvati, Srbi, Šokci, Bunjevci i koliko već imena ima ovaj narod" te da je tiskan na četiri stranice. Folnegović navodi kako je dosadašnje razdoblje mađarske vladavine dovoljan dokaz mađarskih manjinskih prava te kao najjače sredstvo u rukama Mađara za asimilaciju narodnosti ističe rascjepkanost spomenutih zajednica. Kao nastavak ovoga napisa, u sljedećem broju novina (3. kolovoza 1920.) od istog autora, s istim naslovom, čitamo dalje o Našoj Domovini. ${ }^{12}$ Folnegović dalje kritizira mađarsku manjinsku politiku u nedavnoj prošlosti, navodeći kako su zakonom osigurana prava bila samo mrtvo slovo na papiru (misleći vjerojatno

${ }^{108}$ Na primjer: „Što će biti sa Šokcima ispod Mečke?“, Baranjski glasnik, 23. V. 1920., 1-2; M. G., „Dali selidba?“, Baranjski glasnik, 5. VI. 1920., 1-2.

${ }^{109}$ Na primjer: Prijelaz Srba u Baranju 1918. g. - pjesma, 18. prosinca 1919., 2. str.; serija Kroz svetski rat - iz dnevnika jednog dobrovoljca. Pjesme šalje ratar Mišo Marjanović iz Šaroka (mađ. Sárok). Srbiji - pjesma, 18. srpnja 1920., 1. str.; Molba - pjesma, 14. studenog 1920. itd.

${ }^{110}$ Budući da je riječ o izdanjima koja su nastala za vrijeme vladavine Miklósa Horthyja na području Mađarske, o njima će se govoriti u sklopu posebnog rada.

111 Juraj Folnegović, „Naša Domovina“, Baranjski glasnik, 25. VII. 1920, 1-2.

112 Juraj Folnegović, „Naša Domovina“, Baranjski glasnik, 3. VIII. 1920, 1. 
na mađarski zakon o manjinama iz 1868. ${ }^{113}$ te da njima, dakle južnoslavenskim zajednicama, nije potrebna mađarska „naša domovina“ već samo „država Srba, Hrvata i Slovenaca“. ${ }^{114}$

O samom Baranjskom glasniku nalazimo informacije u članku pod naslovom ,Za istinu“. ${ }^{115} \mathrm{U}$ njemu se navodi da je glasnik pokrenut zato što se o ovoj zajednici u matičnoj državi (Kraljevstvu SHS) vrlo malo zna, da se tamošnji tisak skoro uopće ne bavi Baranjom te da je izlaženje glasnika osigurala „sama vlada“ (iz Beograda). O širenju letaka čitamo u kraćem tekstu nepoznatog autora ${ }^{116}$ koji govori o širenju letaka na ulicama Pečuha od strane „hrišćanskih socijalista“. Pored ovog letka, za koji se ne navodi jezik, autor spominje i drugi, koji je napisan na „srpsko-hrvatskom jeziku“ u znaku revizionizma i namijenjen je ,šokačkom i srpskom selu“. Autor je uvjeren da takvi letci nisu potrebni „,našem“ stanovništvu jer ,ako je neki manji deo šokačkog našeg življa i povučeniji usled političke neodredjenosti u pitanju njegovog pripadanja on nikada više neće ni poverovati da je stvoren za Madjara, da mora biti Madjarem najmanje da mora služiti madjarskom ili mu kom drugom narodu“.

U dužem napisu pod naslovom „Od uredništva“"117 obavještavaju se čitatelji Baranjskog glasnika o poskupljenju pretplate. Navode se teška financijska situacija koja proizlazi iz malog broja pretplatnika, male svote (vjerojatno državne) subvencije, visoki tiskarski troškovi (trostruko poskupljenje u roku od godinu dana) i sl. Kao dodatan problem navodi se nepouzdanost baranjske pošte zbog „,nesigurnih osoba u poštanskom osoblju“ (,gde su sve sami strani elementi“") ${ }^{118}$ te neangažiranost intelektualaca, koje „ovde u Baranji nemaju baš naša braća Šokci““. ${ }^{119}$

Zadnji broj Baranjskog glasnika izlazi 14. kolovoza 1921. i na naslovnici donosi tekst pod naslovom „Kucnuo je dvanaesti čas“. ${ }^{120}$ Nepoznati autor opisuje tragičnu situaciju evakuacije, predviđa kaotično stanje, demonizira mađarske vlasti i osuđuje Beograd, koji nije vodio brigu o evakuaciji i zbrinjavanju mogućih iseljenika. Ujedno poziva sve Baranjce da još jednom izađu na ulice, da se održe veliki narodni zborovi, jer još uvijek nije kasno. Isti dan, da-

\footnotetext{
113 1868. évi XLIV. törvénycikk a nemzetiségi egyenjogúság tárgyában.

${ }^{114}$ Folnegović, „Naša Domovina“, 1.

115 „Za istinu“, Baranjski glasnik, 22. VIII. 1920., 1.

116 „Iridentski letak“, Baranjski glasnik, 21. IV. 1921., 4.

117 „Od uredništva“, Baranjski glasnik, 1. V. 1921., 3.

118 Isto.

${ }^{119}$ Isto.

${ }^{120}$ „Kucnuo je dvanaesti čas“, Baranjski glasnik, 14. VIII. 1921., 1.
} 
kle 14. kolovoza, u Pečuhu je pod vodstvom pobunjenog proletarijata proglašena tzv. Baranjska Republika (mađ. Baranyai Magyar-Szerb Köztársaság) na čelu sa slikarom Petrom Dobrovićem, ${ }^{121}$ kao zadnja mogućnost za sprečavanje dolaska mađarske vlasti. Nakon višestrukih opomena Antantinih misija Beograd više nije mogao osigurati potporu Baranjskoj republici te je 20. kolovoza započela primopredaja županijske uprave, a 22. kolovoza mađarske postrojbe ušle su na područje Baranjske županije, čime je završena tridesettromjesečna okupacija Baranje od strane vojske Kraljevine SHS. ${ }^{122}$

\section{Zaključak}

U ovom radu opisano je manjinsko nakladništvo koje nastaje na određenom području (područje današnje Mađarske), u relativno kratkom razdoblju (1918.-1921.), ali zapravo u trima državama koje se temelje na vrlo različitim političkim i ideološkim koncepcijama. Kako je navedeno, svaka od njih imala je u određenoj mjeri nakladništvo za manjine za koje su bile odgovorne državne institucije. Zbog različitih ideoloških koncepcija, nije svaka država na isti način pristupala manjinskom nakladništvu. Navedeno je kako su u slučaju Mađarske Demokratske Republike potrebna daljnja istraživanja; ipak, njena manjinska produkcija vjerojatno nije dosegnula dimenzije Mađarske Sovjetske Republike ili produkciju okupiranog područja južne Mađarske. Dok za vrijeme prve državne formacije poslije rata nije bilo periodičnih izdanja, već se manjinsko nakladništvo za Hrvate temeljilo na sitnom tisku, u preostale dvjema državama nalazimo tjednike koji iziskuju kvalitetan humani kadar i velika financijska sredstva.

Pored razlika, postoji jedna karakteristika koja se uočava u slučaju svih državnih formacija, a to je propagandni karakter tiskovina. Za vrijeme Mađarske Demokratske Republike s raznim letcima se htjelo pridobiti manjinsko stanovništvo za novu mađarsku državu, Sovjetska Republika u Mađarskoj je pristupila istoj publici kako bi stvorila ,savršeno, besklasno društvo potpune jednakosti“" ${ }^{123}$ dok je srpska uprava u Baranji propagirala južnoslavenski/jugoslavenski koncept na okupiranom području. Mada su ova izdanja namijenjena i hrvatskoj zajednici na području današnje Mađarske, njeni članovi (pripadnici hrvatske zajednice s prostora današnje Mađarske) nisu igrali ključnu

${ }^{121}$ Petar Dobrović (Pečuh/Pécs, 1890. - Beograd, 1942.) slikar, studirao u Budimpešti, djelovao u Mađarskoj, boravio i u Parizu. Nakon pada Baranjske republike odlazi iz Mađarske i nastavlja svoje djelovanje u Kraljevini SHS. Mirjana Petričević, "Dobrović, Petar", u: Krležijana, sv. 1, gl. ur. Velimir Visković (Zagreb, 1993), 158-161.

122 Glibonjski, Pécs szerb megszállása egy szerb újságíró szemével, 53-54.

${ }^{123}$ Natuknica „komunizam“ u: Hrvatska enciklopedija, mrežno izdanje, pristup ostvaren 16. VII. 2020. http://www.enciklopedija.hr. 
ulogu u njihovom stvaranju, nisu oni određivali sadržaj, osmislili koncepciju i postavili ciljeve, već je to učinjeno izvan njihove ingerencije.

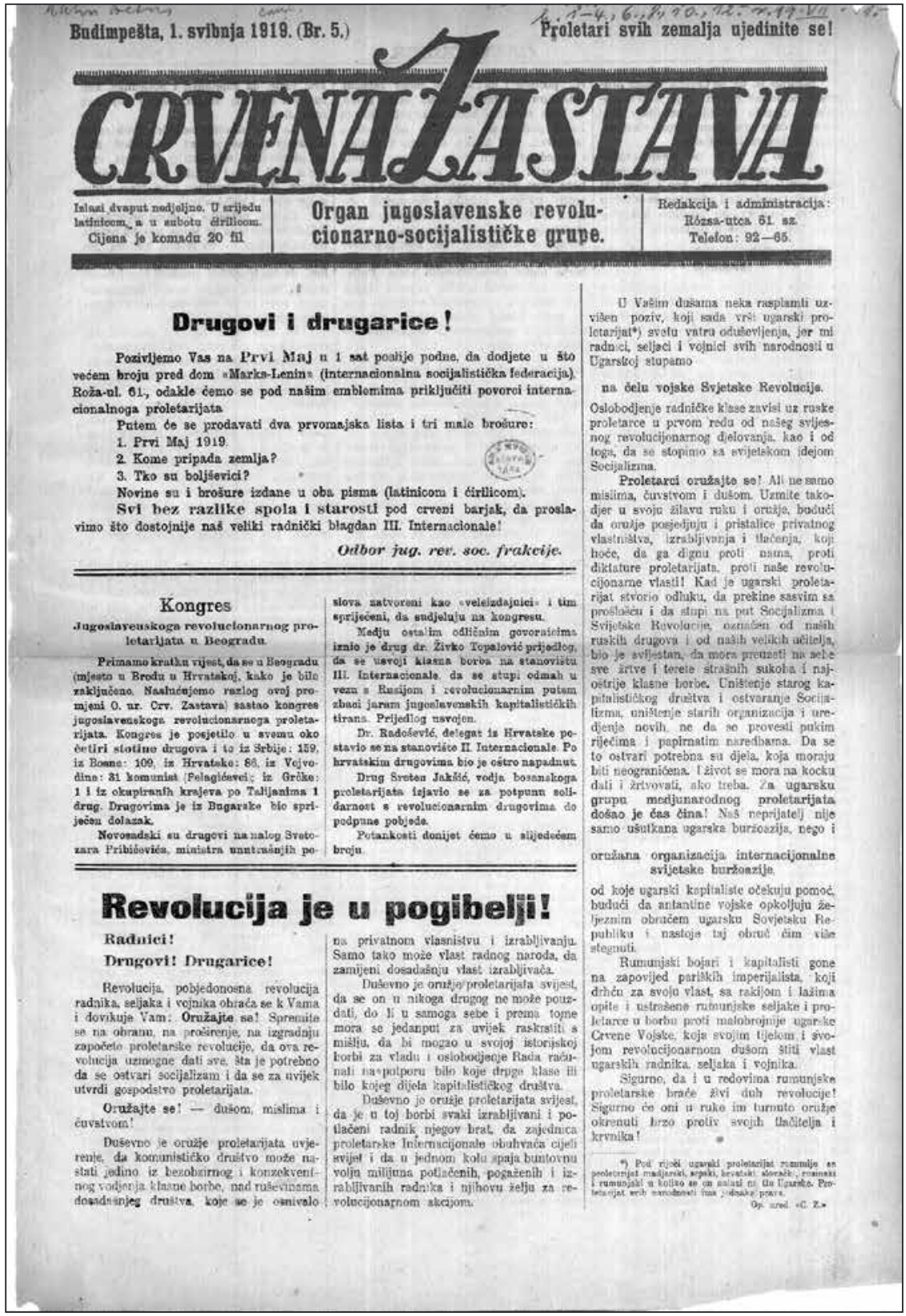

Slika 1: Prvi broj Crvene zastave tiskan latinicom ${ }^{124}$

${ }^{124}$ Iz fonda Državne knjižnice Széchenyi (Országos Széchenyi Könyvtár). 


\section{Literatura}

1. A Magyar Korona országaiban az 1881. év elején végrehajtott népszámlálás eredményei némely hasznos házi állatok kimutatásával együtt. Budapest: Országos Magyar Kir. Statisztikai Hivatal, 1882. (Popis stanovništva iz 1881.)

2. A Magyar Szent Korona országainak 1910. évi népszámlálása: 6. rész: Végeredmények összefoglalása. Budapest: Magyar Kir. Központi Statisztikai Hivatal, 1920.

3. Ács, Zoltán. Nemzetiségek a történelmi Magyarországon. Budapest: Kossuth, 1986.

4. Beller, Béla. „A Magyar Népköztársaság és a Tanácsköztársaság nemzetiségi kultúrpolitikája". Történelmi szemle 1-2, 1969. Budapest: Akadémiai Kiadó, 1969., 1-25.

5. Borsy, Károly. „A pécsi nyomdászat múltjáról”. Pécsi Szemle, 1998. (1. évf.), 1-2. szám. Pécs: 1998., 47-53.

6. „Crvena zastava“, Crvena zastava (Budimpešta), 5. IV. 1919., 1.

7. Demeter, M. Attila. „Politikai nemzet versus nemzetiség - 1848, 1861, 1868”. Nemzet, faj, kultúra a hosszú 19. században Magyarországon és Európában. Budapest: MTA Bölcsészettudományi Kutatóközpont, Történettudományi Intézet, 2016 .

8. „Dr. Prakatur kod kuće“, Baranjski glasnik (Pečuh), 15. VI. 1920., 4.

9. „Drugovi i drugarice!“”, Crvena zastava, (Budimpešta), 1. V. 1919., 1.

10. Eötvös, József báró. A nemzetiségi kérdés. Pest: Ráth Mór, 1865. Pristup ostvaren 30. III. 2020. https://mek.oszk.hu/06800/06839/pdf/06839.pdf

11. Folnegović, Juraj. Naša Domovina. Baranjski glasnik (Pečuh), 25. VII. 1920a, $1-2$.

12. Folnegović, Juraj. Naša Domovina. Baranjski glasnik (Pečuh), 3. VIII. 1920b, 1.

13. Füzes, Miklós (ur.). Nemzetiségi ügyek dokumentumai Baranyában 1923-1938. Pécs: Baranya Megyei Levéltár, 2001.

14. Galántai, József. A Habsburg-monarchia alkonya: Osztrák-magyar dualizmus, 1867-1918. Budapest: Kossuth, 1985.

15. Gj., V., „Srbima!“‘, Baranjski glasnik (Pečuh), 20. XI. 1919., 2-3.

16. Glibonjski, Milan. „Interniranje dr.-a Prakatura“, Baranjski glasnik (Pečuh), 6. V. 1920., 3 .

17. Glibonjski, Milan. „Jedno pismo i moj odgovor na njega“, Baranjski glasnik (Pečuh), 1. V. 1920., 1-2.

18. Glibonjski, Milan. Pécs szerb megszállása egy szerb újságíró szemével. Pécs: Pécs Története Alapítvány, 2006. (Preveo Árpád Hornyák)

19. Glibonjski, Milan. „Šokci i Srbi“, Baranjski glasnik (Pečuh), 18. XII. 1919., 1.

20. Hetés, Tibor (ur.). A magyarországi forradalmak krónikája: 1918-1919. Budapest: Kossuth Könyvkiadó, 1969. 
21. Hornyák, Árpád. „A szerb megszállás Baranyában“. História, 32. éf., 9-10 sz. Budapest: História Alapítvány, 2010., 49-54.

22. Hornyák, Árpád. „Impériumváltás(ok) Pécsen szerb szemmel”. Limes 2005/1. Tatabánya: 2005., 21-40.

23. Iglói, Zoltán (ur.) Pécs-Baranya sajtójának bibliográfiája 1918-1921. Pécs: MSZMP Baranya megyei Bizottsága, Propaganda és Művelődési Osztálya, 1966.

24. „Iridentski letak“, Baranjski glasnik (Pečuh), 21. IV. 1921., 4.

25. Kenyeres, Ágnes (ur.). Magyar életrajzi lexikon. Pristup ostvaren: 16.05.2019., (mrežno izdanje: http://mek.oszk.hu/00300/00355/html/index.html)

26. Kollega Tarsoly, István. Magyarország a XX. században, I-V. Szekszárd: Babits Kiadó, 1996-2000. (http://mek.oszk.hu/02100/02185/html/index.html)

27. Kővágó, László. Internacionalisták a Tanácsköztársaságért. Budapest: Kossuth Könyvkiadó, 1969.

28. „Od uredništva“, Baranjski glasnik (Pečuh), 1. V. 1921., 3.

29. P., D. „Pandurović Vladislav Dr.“, u Narodna enciklopedija srpsko-hrvatskoslovenačka, Knj. 3, 340. Zagreb: Bibliografski zavod, 1928.

30. Petričević, Mirjana. „Dobrović, Petar”. U Krležijana, sv. 1, 158-161. [gl. ur. Velimir Visković, Zagreb: 1993.],

31. Ravlić, Slaven (ur.). Hrvatska enciklopedija, mrežno izdanje. Zagreb: Leksikografski zavod Miroslav Krleža. Pristup ostvaren: 16. 5. 2019. (http://www.enciklopedija.hr)

32. Schönwald, Pál. „Az Országos Propaganda Bizottság tevékenysége és kiadványai az 1918-as polgári forradalom alatt.” Magyar könyvszemle, 1969., 1. szám. Budapest: Akadémiai Kiadó, 1969., 20-28.

33. Sebesi, Judit. „N. Pataki Márta: A Kossuth Nyomda története 1884-1984“. Magyar Grafika 29 (1985), br. 1-2: 94-99.

34. „Srbima čitaocima”, Baranjski glasnik (Pečuh), 30. X. 1919., 4.

35. Stulli, Bernard (ur.). Arhivski vjesnik II. Zagreb: 1959.

36. Szabó, Viktor, A Magyarországi Tanácsköztársaság propagandája. Doktorska disertacija. Eger: Eszterházy Károly Főiskola, Történelemtudományi Doktori Iskola, 2016.

37. „Šokci“, Baranjski glasnik (Pečuh), 6. XI. 1919., 1.

38. Šokčević, Dinko, ,Mađarski politički planovi za rješenje hrvatskog [jugoslavenskog] pitanja“, u: Prekretnice u suživotu Hrvata i Mađara: ustanove, društvo, gospodarstvo i kultura, ur. Pál Fodor, Dinko Šokčević, 73-83. Budimpešta: Institut za povijesne znanosti Istraživačkog centra za humanističke znanosti Mađarske akademije znanosti, Hrvatski institut za povijest, 2015.

39. Tegzes, Ferenc, „A miniszterelnökség délszláv szakreferensének jelentései a baranyai délszlávokról az 1920-as évek első felében“. Baranyai helytörténetírás 1978. Pécs: Baranya megyei Levéltár, 1979., 457-509. 
40. Tilkovszky, Lóránt, Nemzetiségi politika Magyarországon a 20. században. Debrecen: Csokonai, 1998.

41. Tiszay, Andor et al. (ur.), A Magyar Tanácsköztársaság röplapjai: bibliográfia és dokumentumgyüjtemény. Budapest: Fővárosi Szabó Ervin Könyvtár, OSZK, 1959.

42. Vermes, Gábor, „A délszláv törekvések és a magyar nacionalizmus az Osztrák-Magyar Monarchiában“, Aetas 9 (1994), br. 2: 203-222.

43. Visković, Velimir (ur.), Krležijana, mrežno izdanje. Zagreb: Leksikografski zavod Miroslav Krleža. Pristup ostvaren: 16. 5. 2016. (http://krlezijana.lzmk.hr/)

44. „Za istinu“, Baranjski glasnik (Pečuh), 22. VIII. 1920., 1. 


\section{Zusammenfassung}

\section{KROATISCHE PRESSE ÜBER DAS GEBIET DES HEUTE UNGARN IN DEN JAHREN NACH DEM ERSTEN WELTKRIEG}

In den Jahren nach dem Ersten Weltkrieg (1918-1921) änderten sich auf dem Gebiet des heutigen Ungarn mehrere Staatsformationen. Ziel dieser Arbeit ist es, die Existenz kroatischer Ausgaben (Bücher, Periodika, Broschüren und Faltblätter) vorzustellen, die in diesem Zeitraum auf dem genannten Gebiet entstehen und direkt oder indirekt mit staatlich finanzierten Institutionen oder Einzelpersonen in Verbindung stehen. Ausgangspunkt ist ein Verzeichnis kroatischer Publikationen, die von 1918 bis 2015 auf dem Gebiet des heutigen Ungarn veröffentlicht worden sind. Da sich das Minoritäten-Verlagswesen in Ungarn nach dem Ersten Weltkrieg weitgehend auf staatliche Institutionen beruht hat, beschreibt ein Teil der Arbeit die ungarische Minderheitenpolitik dieser Zeit. Mit dem Einblick in das Korpus und den Inhalt der Veröffentlichungen entsteht der Eindruck, dass es sich um einen Verlag mit starkem Propaganda-Charakter handelt.

Schlüsselwörter: Kroaten in Ungarn, Verlagswesen, Minderheitenpolitik, Demokratische Republik Ungarn, Ungarische Räterepublik, serbische Besetzung von Fünfkirchen (Pécs) und Branau (Baranya)

\section{Kontakt autora:}

Silvestar Balić / Bality Szilveszter, znanstveni suradnik

Znanstveni zavod Hrvata u Mađarskoj / Magyarországi Horvátok Tudományos

Intézete, Jókai tér 11. H-7621 Pécs, Mađarska

e-mail: balic.silvester@gmail.com 
